\title{
Biometric Method for the Ossification Evaluation of Children from Birth Up to the Ages of Two and Four - Applied to the Metacarpal and Phalanxes in Spanish Longitudinal Series
}

\author{
Bernardo Ebri ${ }^{1}$, Inmaculada Ebri ${ }^{2}$ \\ 1. Hospital Universitario Miguel Servet de Zaragoza (Spain) 2 . Family Medicine, Hospital Miguel Servet \\ Zaragoza Spain
}

$\square$ Corresponding author: Bernardo Ebri, b.ebri@yahoo.es

Disclosures can be found in Additional Information at the end of the article

Received 09/23/2013

Review began 09/29/2013

Published 06/26/2013

\section{๑) Copyright 2013}

Ebri et al. This is an open access article distributed under the terms of the Creative Commons Attribution License CC-BY 3.0., which permits unrestricted use, distribution, and reproduction in any medium, provided the original author and source are credited.

\section{Abstract}

Aim: This work, based on the Spanish longitudinal growth and development series done at the Andrea Prader Center, Zaragoza, Spain, studied children up to the age of twenty years. It aims to contribute to a practical and accurate numerical method to calculate the bone age of the studied children, from birth to two and four years.

Methods: The total sample of the study was 160 healthy children (73 males and 87 females). Every child underwent annual radiography on his/her left hand at the Miguel Servet Hospital in Zaragoza, Spain. Using measurements of the Tanner II-Rus method, the maximum epiphyseal distances of the subjects were studied.

Results: As a result, we have developed an index called the Metacarpal-Phalanx Index, closely correlated with the chronological age of the child, which creates bone age prediction equations. Another index called "Index Valuation Ossification of the Metacarpal-Phalangeal", obtained through the above, allowed us to compare the results to Gaussian shape equivalences, thus revealing the ossifying status of the child, and whether it is late, early or insignificant.

Conclusions: When using this method, we are able to optimize the calculations of bone age if we apply the general equations to children up to the age of twenty years.

Categories: Endocrinology/Diabetes/Metabolism, Family/General Practice, Radiology

Keywords: bone age calculation, metacarpophalangeal, spanish series, children, indexes

\section{Introduction}

This work's main objective is to provide a numerical method to accurately calculate the bone age of children in the age groups from birth to two and to four years of age. This study is based on the Spanish longitudinal growth and development series, "Andrea Prader" [1], which assesses children from birth to twenty years. The numerical method evaluates the epiphysis of the metacarpal bones and phalanges of the left hand in the same bones of Tanner, et al. [2] but rather by following another dynamic assessment. In our method, we measure the maximum distance from the nuclei of ossification and prepare them as average indices (Ebrí índices), designated as the "Indice Metacarpo-Falangico" (IMF) or "Metacarpal Phalangeal Index" and 
the "Ossification Valuation Index of the Metacarpal-Phalangeal" ( IVOMF ) Ebrí Torne [3] published the "Ossification Evaluation Index of the Tarsus" (OEIT) applied to a Spanish cross-population from birth to age 16, and later, also published [4] the same rate applied to children up to two and four years. The latter publication was better at this age for the predictive equations of general casuistry, relativizing the asynchrony of the nuclei of ossification, and avoiding overestimation of bone age that produced general equations when applied to children. Similarly, in this present work with the metacarpal-phalangeal region, we wanted to provide the practical predictive equations for optimizing bone age prediction for these age groups.

\section{Materials And Methods}

The total sample of the study were 160 healthy children ( 73 males and 87 females) whose left hand was radiographed annually on his or her birthday, at the Hospital Miguel Servet in Zaragoza (Spain), from birth to four years, inclusive. The Research Committee authorized this study by the General Study and Radiological Somatometric Andrea Prader of the Unit of Endocrinology, Hospital Miguel Servet, Zaragoza, Spain. Signed consent was obtained from the parents of all the children. The study was also endorsed and supported by the Government of Aragon [5].

Action films: From birth to two years, there were 162 males and 201 females. From birth to four years, there were 255 males and 326 females. We used the 1956 survey Graffar socioeconomic classification for children [6].

The procedure in every left hand radiograph was to measure the core of the metacarpal and phalangeal epiphyses comprising both the radius and ulna. Maximum distances were measured with vernier nuclear optimally expressing the measurements made and have served as the basis for preparation of the IMF. Such index is expressed in millimeters (mm), and its result, the sum of the maximum diameters of the cores epiphyseal metacarpals and phalanges: I, III and V, as well as the radial and ulnar distal epiphysis in a total 13 cores.

Figure 1 shows the maximum distance measured from the cores of ossification. 


\section{Cureus}

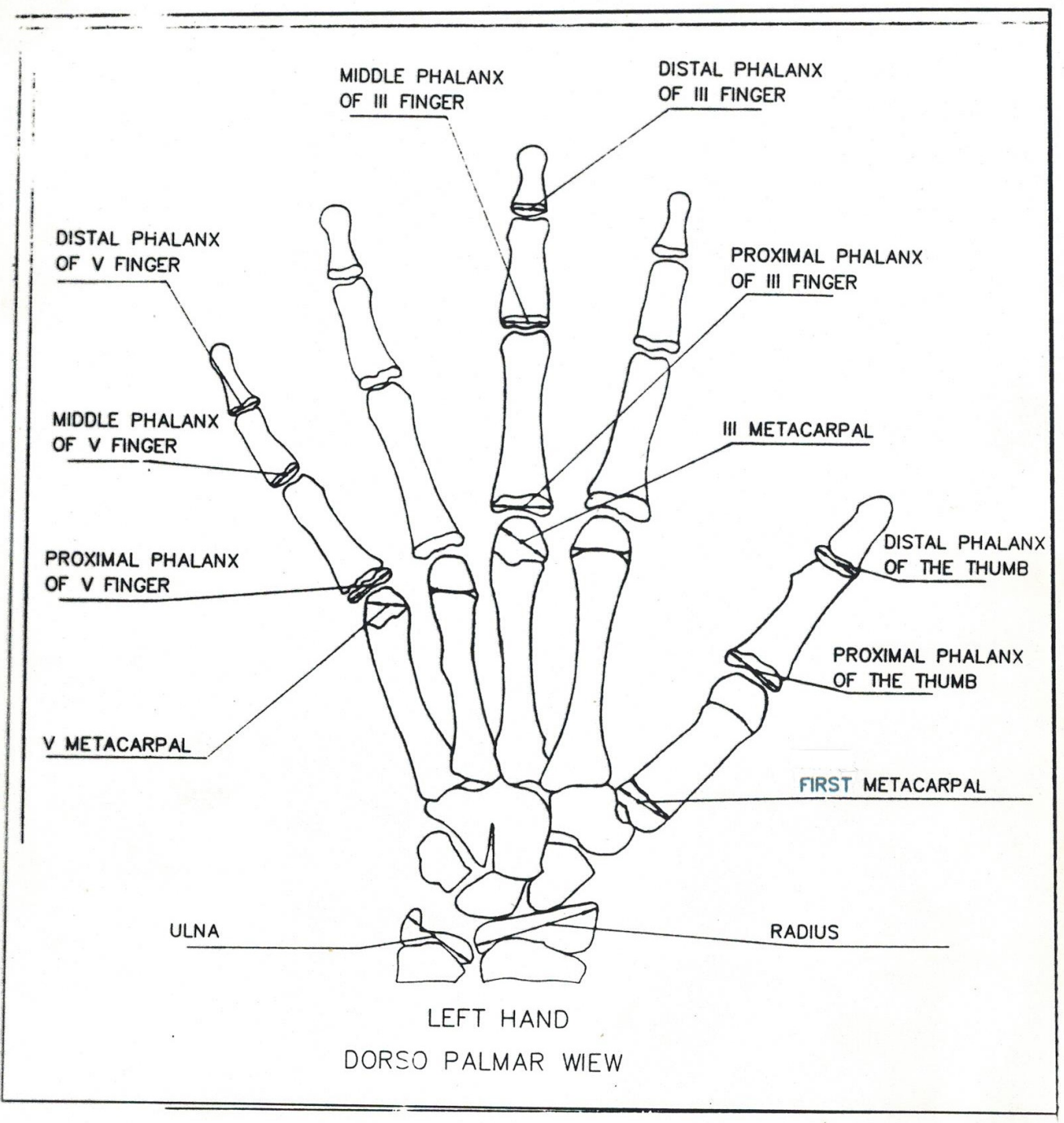

FIGURE 1: Maximum diameters of the Metacarpal ossifying cores

The sum of the existing cores at the time of radiographic measurement is divided by 13 , for simplification of the index number. A fixed number, in all cases, even at the time of measurement, was not present in all cores. All radiographic measurements were performed by a single observer. A repeatability study performed in 100 films, one month after the first measurement, was greater than 95\%. The statistical package, "Statistix software version 9, 2000", was used for statistical work.

Correlation coefficients were made of the two variables, IMF and chronological age, in order to obtain the equation of the regression line for the prediction of the child's bone age. For better optimization of reading the bone age of the child to study, and Gaussian bell graphic expression, was obtained from IMF index, called the "IVOMF" (Ossification Valuation Index of the Metacarpal-Phalangeal), following the same general methodology that Torne Ebrí used in various studies [7-8]. This is the formula applied by this author:

$a+1,96 s d+b$.Index - Age 


\section{Cureus}

IVO

$0,0392 \mathrm{sd}$

\section{Results}

Most of the study population belongs to socioeconomic status III (middle-middle class), 46.2\%.

Category IV (lower middle class) represents $43.9 \%$.

The equations of straight bone ages for male and female, of newborn to two years and newborn to four years, are expressed in Table 1 . Table 1 also specifies the correlation coefficient, number of radiographs, and standard deviation. The statistical significance of the correlations is: $\mathrm{p}$ $<0.001$.

\begin{tabular}{|c|c|c|c|c|c|c|c|}
\hline Sex & Age & Index & a & b & $r^{2}$ & $\mathbf{n}$ & Sd \\
\hline Male & $0-2$ & IMF & 0,82511 & 0,43422 & 0,5022 & 162 & 0,41338 \\
\hline Male & $0-4$ & IMF & 0,87894 & 0,53613 & 0, 8396 & 255 & 0,52085 \\
\hline Female & $0-2$ & IMF & 0,64983 & 0,32671 & 0,8055 & 201 & 0,26527 \\
\hline Female & $0-4$ & IMF & 0,56577 & 0,47442 & 0, 8995 & 326 & 0, 40951 \\
\hline
\end{tabular}

\section{TABLE 1: Equations to find out the Bone Age.}

Bone $\mathrm{Age}=\mathrm{a}+\mathrm{b}$. IMF $\mathrm{a}=$ origin ordinate $\mathrm{b}=$ regression ratio $\mathrm{r} 2=$ co-relation ratio $\mathrm{n}=$ number of radiographies. Sd $=$ typical deviation IMF = Metacarpal-phalanx index in $\mathrm{mm}$, obtained from the radiological measurements.

Table 2 specifies the IVOS formulas for children.

\begin{tabular}{|c|c|c|}
\hline $0-2$ years & Male & IVO-IMF= 100,919 +26,796 x IMF -61,711 x EC \\
\hline $0-4$ years & Male & IVO-IMF = 93,049 +26,259 x IMF -48,978 x EC \\
\hline $0-2$ years & Female & IVO-IMF = 112,492 +31,419 x IMF $-96,167$ x EC \\
\hline $0-4$ years & Female & IVU-IMF = 85,244 +29,554 x IMF -62,294 x EC \\
\hline
\end{tabular}

\section{TABLE 2: Equations to obtain the MF-Ebrí ossifying valuation index}

EC $=$ Chronological Age in years. IMF = Metacarpal-phalanx index in mm, obtained from the radiological measurements.

The results obtained, the values in both sexes, ranging from 0 to 100 ( -1.96 to 1.96 standard deviation) can be brought to a figure of equivalence regarding bone age (Figure 2). The radiograph would show, in this way, a normal, advanced, or delayed ossification and if the lead or lag is significant or not. 


\section{Cureus}

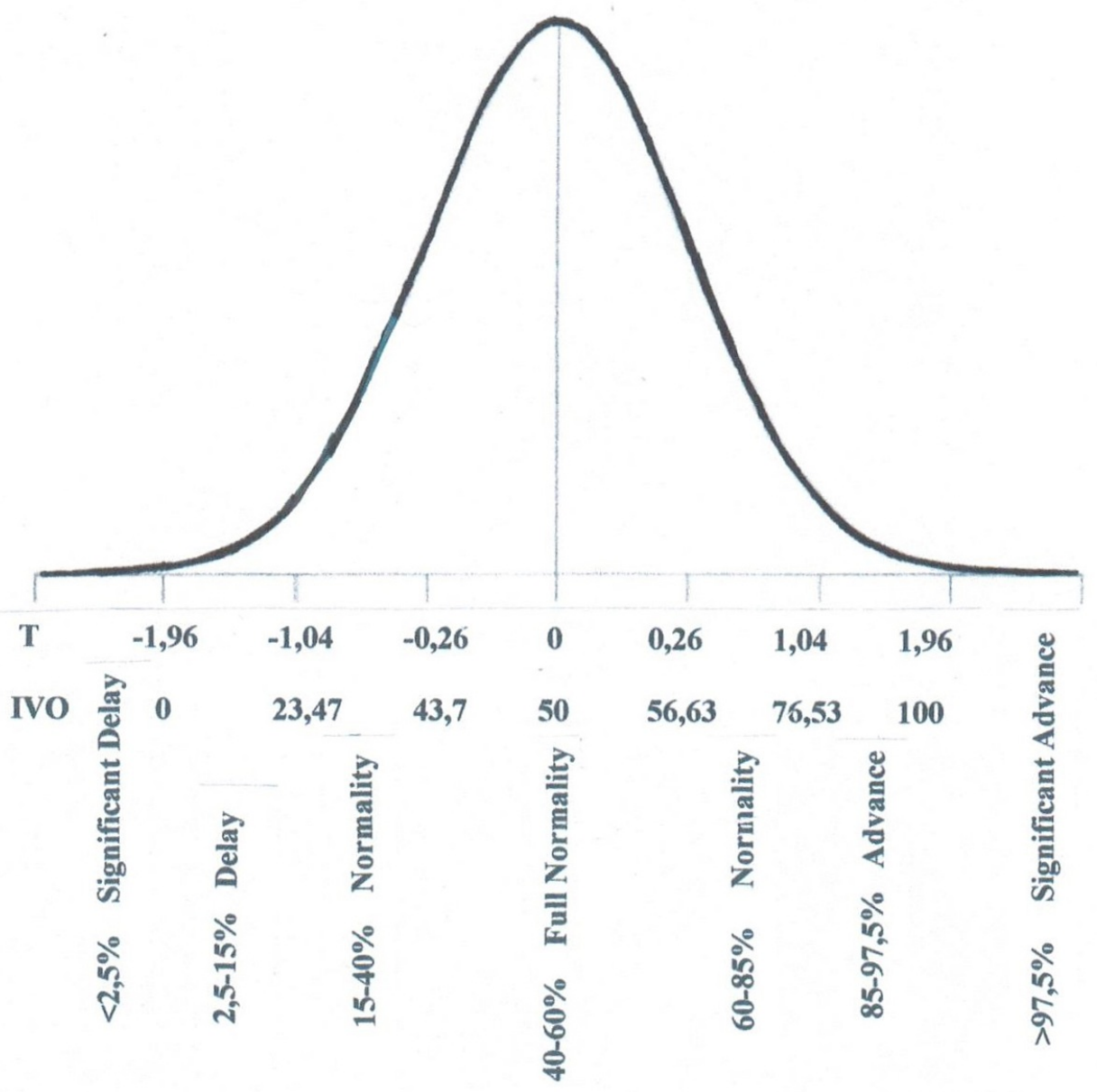

FIGURE 2: IVO equivalences to the bone age

Figure 2 specifies the IVO equivalences to the bone age.

\section{Discussion}

Bone age assessment is frequently used in endocrine pathology to assess milestones of nutrition and growth, as well as to serve as a modern method of predicting adult height and to check the response to suitable treatment for pathologies that may accelerate or retard normal growth. Accurate bone age can also be applied in anthropology, forensics, and school sports, as well as to control children adopted by institutions [9]. IVOMF and IMF are accurate means for bone age determination, allowing the investigator two effective tools for diagnosing predictive bone age in study children. By adjusting the IVOMF at ages newborn to two years and newborn to four years, excluding the rest of older casuistry, the asynchrony of the nuclei of ossification is relativized. This avoids the overestimation in the usual general equations that has occurred when applied to young children. With the figure of equivalences IVO bone age, the diagnosis of bone age can further be simplified. A simple pocket calculator provides a substantial improvement for bone age assessment, so important in the overall assessment of the child.

Ebrí developed the study's methodology in 1992 and 1993 in the application of comparing a longitudinal Swiss population to a Spanish population by using the methods of Greulich and 
Pyle with those of Tanner-Whitehouse [10-11]. In 1996, Ebrí [12] applied his Swiss longitudinal population indices, the same bone Rus TWII studied, by comparing the two methods, checking their compatibility, and found a greater simplicity of bone assessment index

metacarpofalángico compared to complex methodology of the English author. A year later Ebrí [13], in the same Swiss population of 10-22 years, made a comparative study of bone ages of these children by different methods: carpal Tanner, Tanner-Rus, Ebrí carpal, Ebrí metacarpofalángico, and Greulich-Pyle. He checked the concordance between them, even detecting differences, since each methodologically behaved differently. Preference was chosen - the same bones that TWII-Rus analyzed were preferred, as they were more useful than the carpals and correlated better with pubertal changes, being most predictive of adult height [14].

Also, the basic methodically calculated bone age, as presented here, can also be applied prospectively in order to study new or different racial groups for the purpose of creating standards.

\section{Conclusions}

The author presents an accurate and yet simple method to obtain children's bone age in this age range, avoiding the difficulties introduced by asynchronies occurring in only one age.

\section{Additional Information \\ Disclosures}

Human subjects: Consent was obtained by all participants in this study. The Research Committee of the Hospital Universitario Miguel Servet in Zaragoza issued approval Signed consent was obtained from parents of children involved in the study. Animal subjects: All authors have confirmed that this study did not involve animal subjects or tissue. Conflicts of interest: In compliance with the ICMJE uniform disclosure form, all authors declare the following: Payment/services info: All authors have declared that no financial support was received from any organization for the submitted work. Financial relationships: All authors have declared that they have no financial relationships at present or within the previous three years with any organizations that might have an interest in the submitted work. Other relationships: All authors have declared that there are no other relationships or activities that could appear to have influenced the submitted work.

\section{References}

1. Ebrí Torné B, Ebrí Verde B: Ossifying Value Index: Ebrí Metacarpal-phalanx in Aragon lengthwise series (Andrea Prader). An Pediatr (Barc). 2011, 10.1016/j.anped.2011.01.032

2. Tanner JM, Whitehouse RM, Marshall WA, Healy MJ, Goldstein H: Assessment of skeletal maturity and prediction of adult height (TW2 method). Academic Press, London; 1975.

3. Ebrí Torné B: Biometric Method Adaptation to Basic. Acta Paediatr Scand. 1990, 79:1242-3.

4. Ebrí Torné B: Biometric method for the ossification evaluation of children from birth up to the ages of two and four-applied to the tarsus. Acta Paediatr. 1993, 82:872.

5. Ferrández Longás A: Lengthwise Study of Normal Spanish Children from Birth to Adult Age: Anthropometric, pubertal, radiologic, and intellectual data.. Andrea Prader Foundation, Zaragoza; 2005.

6. Graffar M: A method of social qualifying samples of population . Courier C.I.E. 1956, 6:445449.

7. Ebrí Torné B: Bone maturation on carpal and tarsus. Radiological infant clinical study on 5225 children.. Heraldo de Aragón Publishing, Zaragoza; 1988.

8. Ebrí Torné B., Altarriba Farrán J: Presentation of a new biometric method (I.V.O.) for bone age valuation in children. Medizinische Klink. 1979, 214:50-56.

9. Sarria A, Moreno L, Bueno M: Valuation methods of bone maturation. Rev Esp Pediatr. 1985, 41:911. 


\section{Cureus}

10. Ebrí Torné B: Comparative study of Greulich \& Pyle American Atlas of Swiss and Spanish population, through the Bone Age calculation methods of Greulich \& Pyle, and Ebrí carpal. Annals of Miguel Servet Hospital. 1992, 4:83-90.

11. Ebrí Torné B: IVO Carpal of Swiss Child (Lengthwise Study of Zurich) . Acta Pediatr Esp. 1993, 51:651-654.

12. Ebrí Torné B: Metacarpal-phalanx bone valuation index. Swiss Lengthwise Study. Comparative study with Tanner II Rus. Acta Pediatr Esp. 1996, 54:94-102.

13. Ebrí Torné B: Comparative study of bone ages Tanner-Rus, Tanner Carpal, Ebrí carpal, Ebrí Metacarpal-phalanx, and Greulich \& Pyle. Acta Pediatr Esp. 1997, 55:369-374.

14. Ebrí Torné B, Ebrí Verde I: Metacarpal-phalanx and carpal numerical index for bone age calculation and adult height prediction. An Pediatr (Barc). 2012, 76:199-213. 